\title{
Biochemical fingerprints of marine fungi: implications for trophic and biogeochemical studies
}

\author{
Marcelo H. Gutiérrez ${ }^{1,2}$, Jeanett Vera ${ }^{1,3}$, Benjamin Srain ${ }^{1,2}$, Renato A. Quiñones $^{1,4}$, \\ Lars Wörmer $^{5,6}$, Kai-Uwe Hinrichs ${ }^{5,6}$, Silvio Pantoja-Gutiérrez ${ }^{1,2, *}$ \\ ${ }^{1}$ Departamento de Oceanografía, Universidad de Concepción, 4070386 Concepción, Chile \\ ${ }^{2}$ Centro de Investigación Oceanográfica COPAS Sur-Austral (PIA CONICYT), Universidad de Concepción, \\ 4070386 Concepción, Chile
}

${ }^{3}$ Programa de Doctorado en Oceanografía, Departamento de Oceanografía, Universidad de Concepción, 4070386 Concepción, Chile

${ }^{4}$ Centro Interdisciplinario para la Investigación Acuícola, Universidad de Concepción, 4070386 Concepción, Chile

${ }^{5}$ Center for Marine Environmental Sciences (MARUM), University of Bremen, 28359 Bremen, Germany

${ }^{6}$ Department of Geosciences, University of Bremen, 28359 Bremen, Germany

\begin{abstract}
Fungi are ubiquitous in the marine environment, but their role in carbon and nitrogen cycling in the ocean, and in particular the quantitative significance of fungal biomass to ocean biogeochemistry, has not yet been assessed. Determination of the biochemical and stable isotope composition of marine fungi can provide a basis for identifying fungal patterns in relation to other microbes and detritus, and thus allow evaluation of their contribution to the transformation of marine organic matter. We characterized the biochemical composition of 13 fungal strains isolated from distinct marine environments in the eastern South Pacific Ocean off Chile. Proteins accounted for 3 to $21 \%$ of mycelial dry weight, with notably high levels of the essential amino acids histidine, threonine, valine, lysine and leucine, as well as polyunsaturated fatty acids, ergosterol, and phosphatidylcholine. Elemental composition and energetic content of these marine-derived fungi were within the range reported for bacteria, phytoplankton, zooplankton and other metazoans from aquatic environments, but a distinct pattern of lipids and proteins was identified in marine planktonic fungi. These biochemical signatures, and an elemental composition indicative of a marine planktonic source, have potential applications for the assessment of fungal contribution to marine microbial biomass and organic matter reservoirs, and the cycling of carbon and nutrients.
\end{abstract}

KEY WORDS: Marine fungi - Biochemical composition $\cdot$ Lipid $\cdot$ Protein

${ }^{*}$ Corresponding author: spantoja@udec.cl
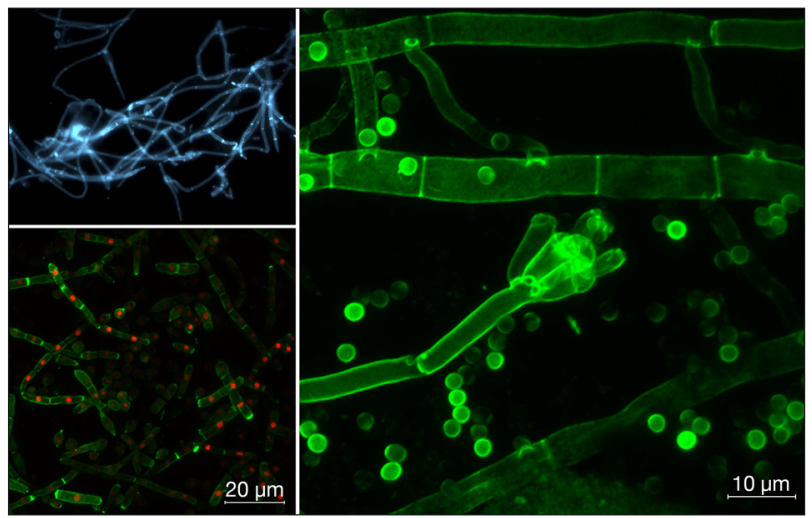

Photographs of epifluorescence microscopy of an environmental sample showing filaments of marine fungus (top left), and of confocal microscopy of strains of marine fungi (bottom left, right).

Photos: Department of Oceanography, University of Concepción, Chile

\section{INTRODUCTION}

In terrestrial environments, fungi contribute some 35 to $76 \%$ of the microbial biomass present within soils (Joergensen \& Wichern 2008) and their pivotal role in nutrient and carbon cycling is widely recognized (Gadd 2006, Crowther et al. 2012, Overy et al. 2014). Although marine fungi are less intensively studied than their terrestrial counterparts, recent research has demonstrated that fungi are present in a wide a variety of marine environments and has unraveled novel aspects of their ecology and bio-

(C) The authors 2020. Open Access under Creative Commons by Attribution Licence. Use, distribution and reproduction are unrestricted. Authors and original publication must be credited. 
geochemical role in the ocean (Gutiérrez et al. 2010, 2011, 2016, Richards et al. 2012, Burgaud et al. 2013, Wang et al. 2014, Fuentes et al. 2015, Bochdansky et al. 2016, Taylor \& Cunliffe 2016, Tisthammer et al. 2016, Wang et al. 2017, Jephcott et al. 2017, Grossart et al. 2019). These findings support inclusion of fungi in models of the marine microbial loop and the oceanic carbon cycle (Gutiérrez et al. 2011, 2016, Cunliffe et al. 2017, Jephcott et al. 2017), but critical gaps in our knowledge have hindered a complete understanding of the role of fungi in marine ecosystems. Information on the elemental and biochemical composition of marine fungi is particularly lacking.

In marine ecosystems, transfer of carbon from primary producers to higher trophic levels involves complex interactions, with microbes playing a central role in the mobilization of dissolved and particulate organic carbon through the microbial loop (Pomeroy 1974, Azam 1998). Indeed, microbial biomass represents a major conduit for organic carbon, with prokaryotes shown to be significant contributors to pelagic trophic webs and carbon fluxes in the ocean (e.g. Azam 1998, Azam \& Malfatti 2007, Falkowski et al. 2008). The few available estimates of fungal biomass have shown it to be similar to that of prokaryotes in surface waters of productive coastal ecosystems (Gutiérrez et al. 2011), and suggest that fungi are therefore significant contributors to living microbial carbon and a potential source of energy for the marine trophic web. Terrestrial fungi are recognized producers of essential organic substrates such as proteins, lipids, vitamins, and other molecules of nutritional value (Feeney et al. 2014), and in aquatic environments fungi have been proposed as potential sources of food for benthic and planktonic organisms (Raghukumar 2002, Kagami et al. 2014). For example, due to the presence of polyunsaturated fatty acids, zoospores of chytrid parasites on phytoplankton could contribute to zooplankton nutrition in freshwater bodies (Kagami et al. 2011) and in the ocean (Gutiérrez et al. 2016).

In order to understand the significance of fungi as reservoirs of organic carbon and nitrogen, and as a source of energy for trophic webs in the ocean, we analyzed the elemental and biochemical composition of marine fungal isolates from several distinctive coastal and oceanic environments of the eastern South Pacific Ocean off Chile. This highly heterogeneous marine environment includes one of the most productive coastal marine ecosystems in the world (Daneri et al. 2000), under the influence of an extensive oxygen minimum zone (Quiñones et al. 2010) and several large rivers (Dávila et al. 2002). In addition, oligotrophic conditions can be observed in the open ocean region, whereas Chilean Patagonia encompasses one of the world's most extensive fjord ecosystems with glacial influence (Pantoja et al. 2011). The variety of environments found in these large Pacific Ocean ecosystems supports different communities of microorganisms (e.g. Quiñones et al. 2009, Ulloa et al. 2012, Gutiérrez et al. 2018), including fungi (Gutiérrez et al. 2015, 2017, Vera et al. 2017). The study is therefore expected to provide a wide range of variability in fungal diversity and, thus, in their elemental and biochemical composition.

\section{MATERIALS AND METHODS}

\subsection{Strain collection, phylogenetic analysis, and preparation of biomass for analysis}

Twelve strains of fungi isolated from the water column and one strain isolated from sediment were obtained from the culture collection of the Marine Organic Geochemistry Laboratory at the University of Concepción, Chile (Table 1), and are available upon request. Isolation of fungal strains was carried out in glucose-yeast extract agar (Johnson \& Sparrow 1961, Kohlmeyer \& Kohlmeyer 1979) prepared with sterile natural seawater. Biomass for elemental and biochemical analysis was obtained by growing fungal mycelia in liquid Emerson's YpSs media prepared in sterile seawater containing yeast extract, soluble starch, dipotassium phosphate, and magnesium sulfate (Kohlmeyer \& Kohlmeyer 1979). Incubations were conducted at $20^{\circ} \mathrm{C}$ in a shaker until mycelia were clearly distinguishable $(7 \mathrm{~d})$. Strains were selected from areas with contrasting oceanographic conditions (Fig. 1): the surface waters of the productive coastal upwelling ecosystem of central Chile, the oxygen minimum zone off northern and central Chile, oligotrophic oceanic waters near Easter Island, and estuarine waters of the Patagonian fjords.

Isolation of fungi, DNA extraction and amplification are described in Vera et al. (2017), and are based on White et al. (1990) and Gardes \& Bruns (1993). PCR products, including ITS 1, 5.8 S and ITS 2 regions, were sequenced using the Automated DNA Sequencing Service of MACROGEN (http://dna.macrogen.com/eng). Genera and species were identified by matching sequences with those stored in GenBank, based on previous definitions of ITS rDNA in fungi using BLAST (National Center 
Table 1. Elemental and $\mathrm{C}$ and $\mathrm{N}$ stable isotopic composition, caloric content and abundance of major classes of organic molecules in marine fungal strains (\%: \% dry weight, \%o: delta notation, dw: dry weight, ND: no data)

\begin{tabular}{|c|c|c|c|c|c|c|c|c|c|c|c|c|c|c|}
\hline $\begin{array}{l}\text { Strain } \\
\text { GOM } \\
\text { ID }\end{array}$ & Taxonomy & $\begin{array}{l}\text { Latitude } \\
\text { Longitude }\end{array}$ & $\begin{array}{l}\text { Sampling } \\
\text { site }\end{array}$ & $\begin{array}{l}\text { Depth of } \\
\text { collection } \\
\text { (m) }\end{array}$ & $\begin{array}{l}\mathrm{C} \\
(\%)\end{array}$ & $\begin{array}{l}\delta^{13} \mathrm{C} \\
(\% \circ)\end{array}$ & $\begin{array}{c}\mathrm{N} \\
(\%)\end{array}$ & $\begin{array}{c}\delta^{15} \mathrm{~N} \\
(\%)\end{array}$ & $\begin{array}{l}\mathrm{C} / \mathrm{N} \\
\text { molar }\end{array}$ & $\underset{\mathrm{g}^{-1} \mathrm{dw}}{\mathrm{kcal}}$ & $\begin{array}{c}\text { THAA } \\
(\mathrm{mg} \\
\left.\mathrm{g}^{-1} \mathrm{dw}\right)\end{array}$ & $\begin{array}{l}\text { FAMEs } \\
(\mathrm{mg} \\
\left.\mathrm{g}^{-1} \mathrm{dw}\right)\end{array}$ & $\begin{array}{l}\text { Sterols } \\
(\mathrm{mg} \\
\left.\mathrm{g}^{-1} \mathrm{dw}\right)\end{array}$ & $\begin{array}{c}\text { IPLs } \\
(\mathrm{mg} \\
\left.\mathrm{g}^{-1} \mathrm{dw}\right)\end{array}$ \\
\hline BR1 & Penicillium sp. & $\begin{array}{l}20.83^{\circ} \mathrm{S} \\
70.80^{\circ} \mathrm{W}\end{array}$ & $\begin{array}{l}\text { Upwelling } \\
\text { north Chile }\end{array}$ & 5 & 18.4 & -25.7 & 2.0 & 0.20 & 10.8 & 3.6 & 60.2 & 0.43 & 0.07 & 31.6 \\
\hline BR11 & Penicillium sp. & $\begin{array}{l}20.83^{\circ} \mathrm{S} \\
70.80^{\circ} \mathrm{W}\end{array}$ & $\begin{array}{l}\text { Upwelling } \\
\text { north Chile }\end{array}$ & 5 & 26.3 & -26.2 & 3.0 & 0.25 & 10.3 & 3.8 & 44.6 & 2.77 & 0.11 & 12.6 \\
\hline BR5 & $\begin{array}{l}\text { Penicillium } \\
\text { brevicompactum }\end{array}$ & $\begin{array}{l}20.83^{\circ} \mathrm{S} \\
70.80^{\circ} \mathrm{W}\end{array}$ & $\begin{array}{l}\text { Upwelling } \\
\text { north Chile }\end{array}$ & 70 & 16.9 & -26.0 & 1.1 & 0.02 & 17.3 & 3.5 & 59.4 & 1.14 & 0.02 & 17.5 \\
\hline BR71 & Unidentified yeast & $\begin{array}{c}26.14^{\circ} \mathrm{S} \\
103.57^{\circ} \mathrm{W}\end{array}$ & $\begin{array}{l}\text { Oligotrophic ocean } \\
\text { near Easter Island }\end{array}$ & 1000 & ND & ND & ND & ND & ND & ND & ND & 0.73 & 0.09 & 6.4 \\
\hline BR74 & $\begin{array}{l}\text { Rhodotorula } \\
\text { mucilaginosa }\end{array}$ & $\begin{array}{c}26.14^{\circ} \mathrm{S} \\
103.57^{\circ} \mathrm{W}\end{array}$ & $\begin{array}{l}\text { Oligotrophic ocean } \\
\text { near Easter Island }\end{array}$ & 400 & 31.2 & -24.4 & 4.4 & 4.88 & 8.2 & 4.2 & 187.4 & 0.61 & 0.10 & 6.3 \\
\hline $\mathrm{CH} 113$ & Lecanicillium sp. & $\begin{array}{l}36.5^{\circ} \mathrm{S} \\
3.1^{\circ} \mathrm{W}\end{array}$ & $\begin{array}{l}\text { Upwelling } \\
\text { central Chile }\end{array}$ & 5 & 25.7 & -25.8 & 4.0 & -0.04 & 7.5 & 3.9 & 209.5 & 0.39 & 0.50 & 13.3 \\
\hline CH114 & Fusarium sp. & $\begin{array}{l}36.5^{\circ} \mathrm{S} \\
73.1^{\circ} \mathrm{W}\end{array}$ & $\begin{array}{l}\text { Upwelling } \\
\text { central Chile }\end{array}$ & 80 & 19.4 & -25.9 & 2.3 & 0.91 & 9.8 & 3.1 & 79.6 & 3.00 & 0.12 & 15.7 \\
\hline CH115 & Penicillium & $\begin{array}{l}36.5^{\circ} \mathrm{S} \\
73.1^{\circ} \mathrm{W}\end{array}$ & $\begin{array}{l}\text { Upwelling } \\
\text { central Chile }\end{array}$ & 80 & 21.0 & -26.0 & 1.8 & 0.10 & 13.4 & 3.2 & 37.9 & 1.03 & 0.59 & 13.2 \\
\hline CH131 & $\begin{array}{l}\text { Cladosporium } \\
\text { sphaerospermum }\end{array}$ & $\begin{array}{l}36.38^{\circ} \mathrm{S} \\
72.89^{\circ} \mathrm{W}\end{array}$ & $\begin{array}{l}\text { Upwelling } \\
\text { central Chile }\end{array}$ & 10 & 23.4 & -25.3 & 2.5 & 3.23 & 10.9 & 3.5 & 32.3 & 0.78 & 0.09 & 13.5 \\
\hline CH132 & Mucor circinelloides & $\begin{array}{l}36.5^{\circ} \mathrm{S} \\
73.1^{\circ} \mathrm{W}\end{array}$ & $\begin{array}{l}\text { Upwelling } \\
\text { central Chile }\end{array}$ & $\begin{array}{c}\text { Surface } \\
\text { sediment }\end{array}$ & 23.8 & -25.4 & 3.4 & 0.47 & 8.3 & 3.4 & 64.0 & 1.51 & 0.33 & 10.8 \\
\hline CH58 & Penicillium sp. & $\begin{array}{l}36.5^{\circ} \mathrm{S} \\
73.1^{\circ} \mathrm{W}\end{array}$ & $\begin{array}{l}\text { Upwelling } \\
\text { central Chile }\end{array}$ & 5 & 23.7 & -26.3 & 2.3 & -0.15 & 12.2 & 3.3 & 125.8 & 0.15 & 0.37 & 9.1 \\
\hline CH92 & Penicillium sp. & $\begin{array}{l}47.41^{\circ} \mathrm{S} \\
73.57^{\circ} \mathrm{W}\end{array}$ & $\begin{array}{l}\text { Patagonian } \\
\quad \text { fjord }\end{array}$ & 0 & 30.5 & -26.5 & 2.8 & 0.27 & 12.9 & 3.7 & 57.0 & 0.03 & 0.01 & 3.5 \\
\hline CH82 & Penicillium sp. & $\begin{array}{l}47.41^{\circ} \mathrm{S} \\
73.57^{\circ} \mathrm{W}\end{array}$ & $\begin{array}{l}\text { Patagonian } \\
\text { fjord }\end{array}$ & 0 & 25.3 & -26.0 & 1.6 & 0.18 & 18 & 3.4 & 87.2 & 0.28 & 0.06 & \\
\hline $\begin{array}{l}\text { Average } \\
\text { SD }\end{array}$ & & & & & $\begin{array}{c}23.8 \\
4.4\end{array}$ & $\begin{array}{l}-25.8 \\
0.6\end{array}$ & $\begin{array}{l}2.6 \\
1.0\end{array}$ & $\begin{array}{l}0.9 \\
1.6\end{array}$ & $\begin{array}{c}12 \\
3\end{array}$ & $\begin{array}{l}3.6 \\
0.3\end{array}$ & $\begin{array}{l}87.1 \\
57.8\end{array}$ & $\begin{array}{l}0.99 \\
0.94\end{array}$ & $\begin{array}{l}0.19 \\
0.19\end{array}$ & $\begin{array}{c}12.8 \\
7.2\end{array}$ \\
\hline $\begin{array}{l}\text { Culture } \\
\text { medium }\end{array}$ & & & & & 40.3 & -25.5 & 7.2 & 0.02 & 6.5 & & & & & \\
\hline
\end{tabular}

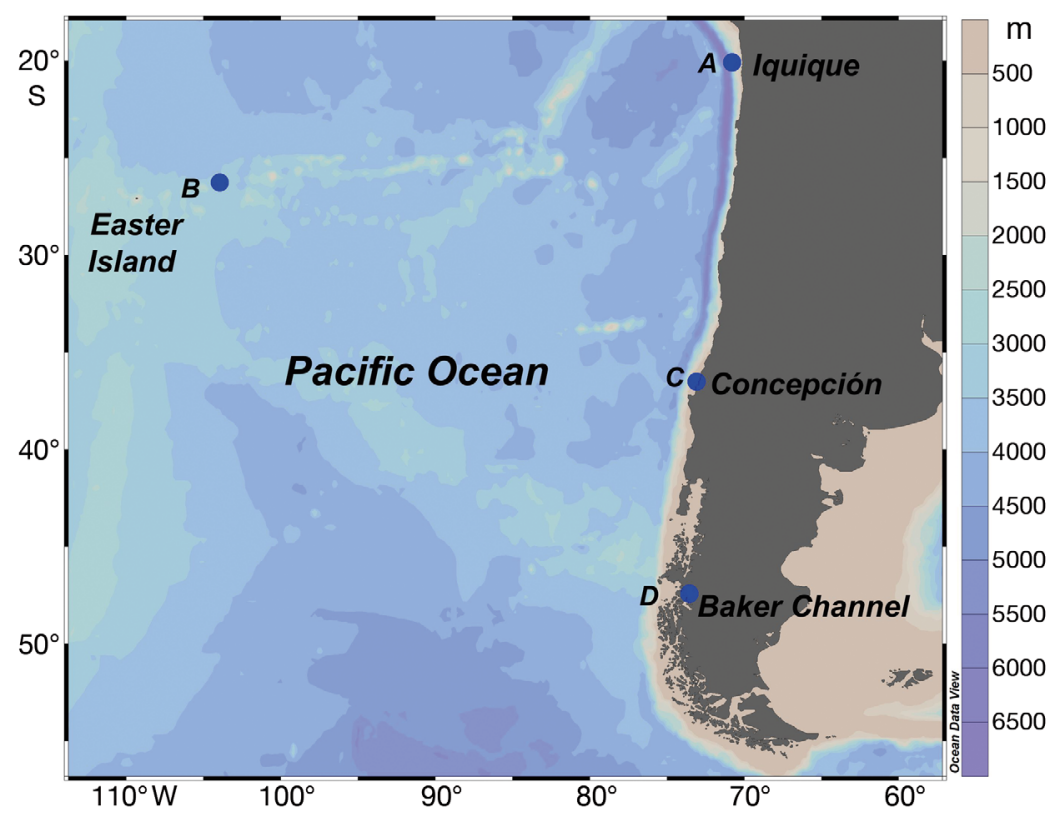

Fig. 1. Sampling areas in the eastern South Pacific Ocean off Chile. A: Oxygen Minimum Zone off Iquique, northern Chile, B: South Pacific subtropical gyre near Easter Island, C: Coastal upwelling ecosystem of central Chile off Concepción, and D: Baker Fjord in Chilean Patagonia for Biotechnology Information, NCBI). Sequences with $99 \%$ nucleotide identity with sequences from GenBank were considered to represent the same species, and sequences with a $97 \%$ match were considered to be from the same genus (Kurtzman \& Robnett 1998, Gao et al. 2008). Sequences larger than $600 \mathrm{bp}$ and their matched sequences from GenBank were aligned with ClustalW (Thompson et al. 1994). A Bayesian tree was computed using MrBayes v.3.2.5 (Ronquist et al. 2012) to identify evolutionary relationships among individual sequences. Analysis was performed using a GTR (General Time Reversible) model selected in PhyML 3.0 (Guindon et al. 2010) run for 30000000 generations until standard deviation of split frequencies was under 0.01. Two parallel runs were computed with 4 chains each, sam- 
pling every 200 generations, with diagnostics calculated every 1000 generations. Bayesian probabilities were considered reliable when higher than $0.95 \mathrm{pp}$ (posterior probabilities) (Murphy et al. 2001, Wilcox et al. 2002, Alfaro \& Holder 2006, Houbraken et al. 2011). Sequences have been submitted to the NCBA GenBank database with accession numbers MH231237-MH231248.

\subsection{Organic carbon and nitrogen content, $\mathrm{C}$ and $\mathrm{N}$ stable isotopic composition, and caloric content}

The $\mathrm{C}$ and $\mathrm{N}$ content and stable isotope composition of organic matter in fungal mycelia and dry culture medium were measured using a continuous flow isotope ratio mass spectrometer coupled to an on-line elemental analyzer at the UC Davis Stable Isotope Facility. The long-term standard deviation was $0.2 \%$ for $\delta^{13} \mathrm{C}$ and $0.3 \%$ for $\delta^{15} \mathrm{~N}$, and the limits of detection were $20 \mu \mathrm{g} \mathrm{N}$ and $100 \mu \mathrm{g} \mathrm{C}$. The caloric content of mycelia was measured in triplicate using a Parr 6725 Semi-micro Oxygen Bomb Calorimeter following the manufacturer's standard methodology (Parr Instrument Company). The edible fungus Agaricus bisporus and the crustacean Euphausia pacifica were used for comparison. The coefficient of variation for replicate measurements of caloric content was $0.3 \%$.

\subsection{Total hydrolysable amino acids (THAA)}

THAA were determined according to the method of Lindroth \& Mopper (1979). Freeze-dried mycelia (100 mg) were suspended in $2 \mathrm{ml}$ of hydrolysis solution $(7 \mathrm{~N} \mathrm{HCl}, 1 \%$ phenol, $10 \%$ trifluoroacetic acid) and purged for 1 min under a pure nitrogen stream. Aliquots of samples were hydrolyzed at $150^{\circ} \mathrm{C}$ for $1.5 \mathrm{~h}$, neutralized ( $\mathrm{pH}$ 6.5-7.5) with $\mathrm{NaOH}$, and derivatized using ortho-phthalaldehyde and mercaptoethanol. Aliquots of derivatized samples were then diluted to $1 \mathrm{ml} 40 \%$ methanol and water and analyzed through high performance liquid chromatography (HPLC) using a Shimadzu chromatograph with fluorescence detector, autosampler, oven, and binary pump. Amino acids were separated on a Kromasil 100-5 C18 column $(4.6 \times$ $250 \mathrm{~mm}$ ) at a constant temperature of $40^{\circ} \mathrm{C}$. A gradient of $25-30 \%$ methanol in $35 \mathrm{~min}, 30-50 \%$ in $7 \min , 50-60 \%$ in $18 \mathrm{~min}, 60-100 \%$ in $12 \mathrm{~min}$ at a flow rate of $1 \mathrm{ml} \mathrm{min}{ }^{-1}$ was used. The column was re-equilibrated with sodium acetate/tetrahydrofuran solution for 5 min between injections. Identification and quantification of amino acids was carried out by co-injection of samples with THAA standard Pierce 20088. Analytical error of determination (coefficient of variation) for duplicate samples was $9.4 \%$ for amino acid analysis.

\subsection{Fatty acid methyl esters (FAMEs) and sterols}

Extraction of lipids from ca. $1 \mathrm{~g}$ dry fungal mycelia (exact weight determined on a micro-analytical balance) was carried out with dichloromethane/ methanol (3:1 v/v) using sonication and centrifugation. The organic phase was separated by adding water and hexane to the extract, and the hexane phase was then concentrated with a rotary evaporator (Bligh \& Dyer 1959). Lipid extracts were split for fatty acid and sterol analyses.

For analysis of fatty acids, extracts were saponified with $15 \mathrm{ml} 0.5 \mathrm{~N} \mathrm{KOH}: \mathrm{MeOH}$ (Christie 1998) and non-saponifiable lipids then separated with hexane. Remaining aqueous extracts were acidified with $6 \mathrm{~N}$ $\mathrm{HCl}$ and fatty acids extracted with hexane. The solvent was removed by rotary evaporation and the fatty acids converted to methyl esters (FAMEs) with $1 \mathrm{ml} 10 \% \mathrm{BF}_{3} / \mathrm{MeOH}$ for $1 \mathrm{~h}$ at $70^{\circ} \mathrm{C}$ (Christie 1998, Tolosa et al. 2004, Méjanelle \& Laureillard 2008). Milli-Q water $(1 \mathrm{ml})$ was added to the mixture and FAMEs were extracted with hexane and dried under a stream of nitrogen. FAME fractions were re-dissolved in $200 \mu \mathrm{l}$ hexane and then injected into a gas chromatograph-mass spectrometer (GC-MS) with a HP5-MS column $(30 \mathrm{~m} \times 0.25 \mathrm{~mm}, 0.25 \mu \mathrm{m}$ film thickness, Agilent Technologies). FAMEs were identified based on retention times (FAME mix, Supelco Analytical), referring to mass spectra in the internal library of the mass spectrometer and electronic database www.lipidhome.co.uk/ms/methesters/ me-arch/index.htm. Quantification was carried out using a calibration curve with serial dilutions of FAME standard mix. The coefficient of variation for fatty acid analysis, measured in 5 replicate analyses, was $14 \%$.

For analysis of sterols, extracts were separated into 4 fractions by column chromatography using columns of $10 \mathrm{~cm}$ length, $0.5 \mathrm{~cm}$ ID, filled with approximately $0.9 \mathrm{~g}$ deactivated silica gel. Aliphatic hydrocarbons were eluted with $40 \mathrm{ml}$ hexane, ketones were eluted with $50 \mathrm{ml}$ toluene/hexane $(1: 3 \mathrm{v} / \mathrm{v})$, alcohols with $50 \mathrm{ml}$ ethyl-acetate/hexane $(1: 9 \mathrm{v} / \mathrm{v})$, and polar compounds were eluted with $35 \mathrm{ml}$ ethyl acetate/methanol/hexane (4:4:1 by vol- 
ume). Alcohol fractions were derivatized with $80 \mu \mathrm{l}$ BSTFA (N,O-bis(trimethylsilyl) trifluoracetamide) and $40 \mathrm{\mu l}$ TMCS (trimethylchlorosilane) at $70^{\circ} \mathrm{C}$ for $1 \mathrm{~h}$ before analysis. Derivatized solutions were injected $(1 \mu \mathrm{l})$ into a GC-MS equipped with a HP5-MS chromatographic column $(30 \times 0.2 \mathrm{~mm}, 0.25 \mu \mathrm{m}$ film thickness, Agilent Technologies). Identification of sterols was achieved by analyzing mass spectra and referring to available mass spectrometry data of sterols (online lipid library: www.chemspider.com). Sterol concentration was determined using internal standards of 1-nonadecanol (5 $\mu \mathrm{g})$. The coefficient of variation for sterol analysis, measured in 10 replicate analyses, was $12 \%$.

\subsection{Intact polar lipids (IPLs)}

Freeze-dried fungal isolates were amended with 1-O-hexadecyl-2-acetyl-sn-glycero-3-phosphocholine (PAF, Avanti Polar Lipids, Alabaster, USA) as an internal standard and lipids were extracted by sonication for 15 min with a methanol, dichloromethane, and phosphate buffer (2:1:0.8 by volume) at $\mathrm{pH} 7.4$, repeated 4 times. Phase separation was improved by adding dichloromethane and buffer to reach ratios of 1:1:0.8 (Bligh \& Dyer 1959, Sturt et al. 2004). Combined extracts were washed with distilled water, the organic phase was evaporated under a stream of nitrogen, and lipids were then stored at $-20^{\circ} \mathrm{C}$.

IPLs were analyzed using reversed phase UHPLC and a high-resolution quadrupole time-of-flight mass spectrometer (Q-TOF) with electrospray ionization (Wörmer et al. 2013). Extracts were dissolved in dichloromethane/methanol $(1: 9 \mathrm{v} / \mathrm{v})$ and lipids separated using an Acquity UPLC BEH C18 RP column $(1.7 \mu \mathrm{m}, 2.1 \times 150 \mathrm{~mm}$, Waters $)$. Eluent A was methanol/water $(85: 15 \mathrm{v} / \mathrm{v})$ with $0.04 \% \mathrm{HCOOH}$ and $0.1 \% 14.8 \mathrm{M} \mathrm{NH}_{3 \mathrm{aq}}$, and eluent $\mathrm{B}$ was isopropyl alcohol/methanol (50:50 v/v) with $0.04 \%$ $\mathrm{HCOOH}$ and $0.1 \% 14.8 \mathrm{M} \mathrm{NH}_{3 \mathrm{aq}}$. The gradient was $100 \%$ eluent A for 2 min, followed by a linear gradient ramp to $85 \%$ eluent $\mathrm{B}$ at $18 \mathrm{~min}$, washing with $100 \%$ eluent B for 8 min and equilibration for $6 \mathrm{~min}$ at $0.4 \mathrm{ml} \mathrm{min}{ }^{-1}$. A full scan was obtained at 2 scans per second, then the 5-10 dominant ions from the MS full scan were subjected to fragmentation to create MS2 spectra (data dependent mode, cf. Wörmer et al. 2013).

IPLs were identified according to retention time, exact precursor ion mass and characteristic fragmentation patterns, and then quantified by comparison of signal intensity to intensity of the internal standard added. No response factors were used for individual IPL classes. Standard deviation of signal intensity was below $10 \%$ in 4 replicate analyses of one sample spiked with standard C16 Lyso PAF.

\subsection{Statistical analyses}

Principal component analysis for amino acid and fatty acid composition of fungi and planktonic components was carried out in $\mathrm{R}$ (version 3.1.2; R Core Team) using the package ggbiplot. Nonparametric Mann-Whitney $U$-tests were applied to test for statistical differences in elemental composition, energetic content and concentration of organic molecules across depth classes and geographic regions. Due to the low number of observations for some depths and regions, statistical tests were not applicable in all cases. The Spearman correlation index was used to analyze associations between elemental composition and concentration of organic molecules.

\section{RESULTS}

\subsection{Taxonomic identification of fungal strains}

Topology of the Bayesian tree indicated that most strains analyzed belonged to the phylum Ascomycota, whereas only one strain was found to belong to each of the phyla Basidiomycota and Zygomycota (Fig. 2). Among the Ascomycota, most isolates belonged to the genus Penicillium, with one member recovered from subsurface suboxic waters of the coastal ocean off northern Chile identified as P. brevicompactum (strain BR5, Fig. 2) in a well-supported branch (1.00 pp). In contrast, strains CH82, CH92, CH58, CH115, BR1, and BR11, isolated from diverse areas and depths of the eastern South Pacific Ocean, showed low probability values $(<0.95)$, providing insufficient support for identification at species level within the genus Penicillium (Fig. 2). Other strains belonging to the phylum Ascomycota included isolates from waters of the coastal upwelling ecosystem of central-south Chile, identified as Cladosporium sphaerospermum (strain CH131), Fusarium sp. (CH114) and Lecanicillium sp. (CH113) in strongly supported clades (1.00 pp, Fig. 2).

Among the Basidiomycota and Zygomycota, strain BR74 - isolated from the deep waters of the South Pacific subtropical gyre near Easter Island (Site B 
Fig. 2. Bayesian tree inferred from ITS sequences of fungi isolated from the eastern South Pacific Ocean off Chile. The tree was validated using Outgroup Orpinomyces sp. AJ864475. Strains used in this study are shown in blue. Strain BR71 was cultured and analyzed for content of FAMEs, sterols and IPL, but not for DNA

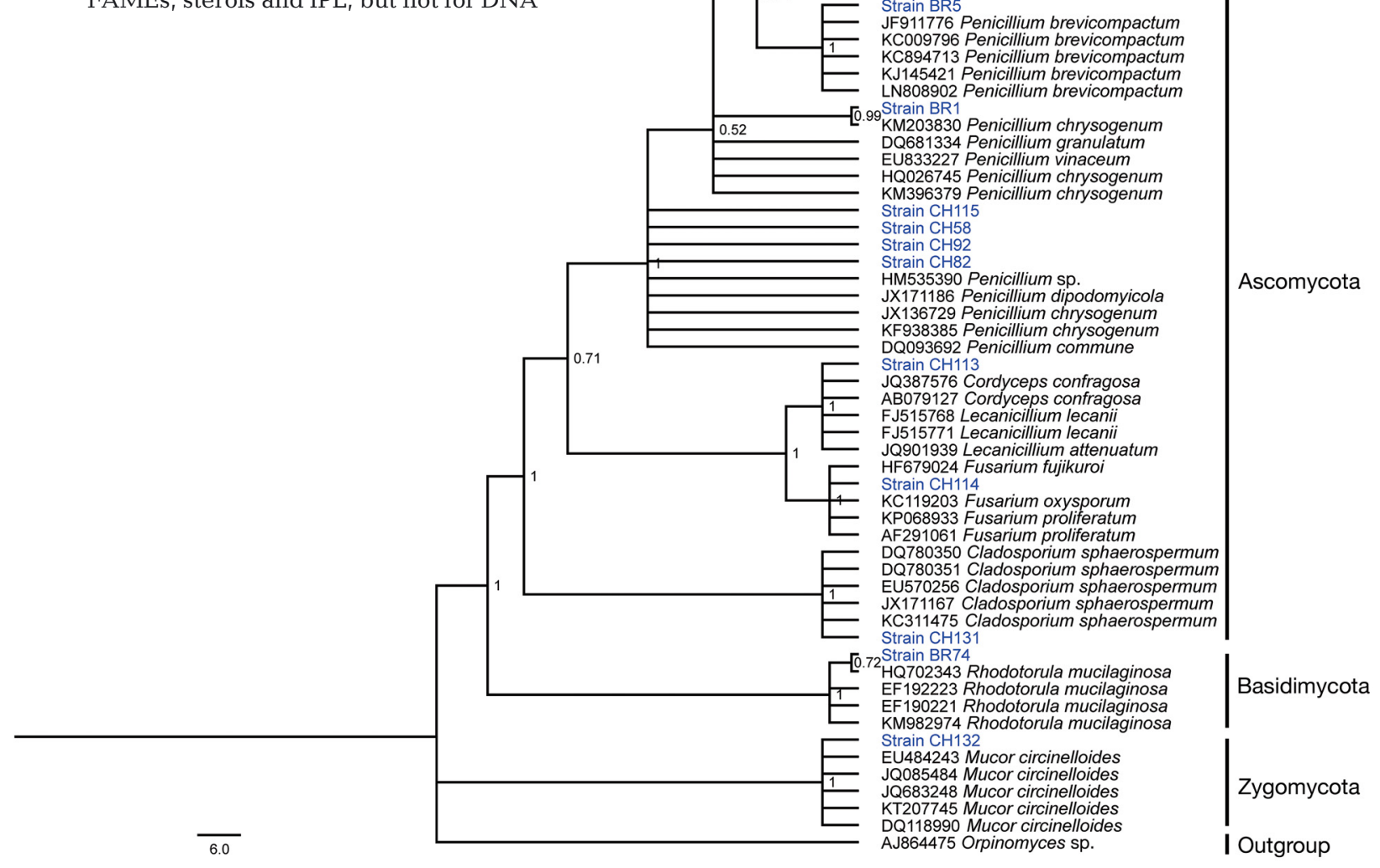

in Fig. 1) - was affiliated with the yeast Rhodotorula mucilaginosa in a strongly supported branch $(1.00 \mathrm{pp})$. Strain CH132 from sediment of the coastal upwelling ecosystem off central Chile was affiliated (1.00 pp) with Mucor circinelloides (Fig. 2).

\subsection{Carbon, nitrogen, caloric content and stable isotope compositions of $\mathrm{C}$ and $\mathrm{N}$ in fungal isolates}

Carbon content of fungal strains ranged from 17 to $31 \%$ and nitrogen content ranged from 1.1 to $4.4 \%$ of dry weight ( $\mathrm{dw}$ ) (Table 1). The highest $\mathrm{C}(31 \%)$ and $\mathrm{N}(4 \%)$ content was found in the yeast $R$. mucilaginosa, isolated from the deep water near Easter Island (Table 1, Site B in Fig. 1). In contrast, P. brevicompactum, isolated from coastal subsurface waters of northern Chile (Site A in Fig. 1) showed the lowest C and $\mathrm{N}$ content (Table 1). Molar $\mathrm{C}$ to $\mathrm{N}$ ratio averaged $11.7 \pm 3.4$, with the highest ratios observed for Peni- cillium isolated from waters of Patagonian fjords (Site D in Fig. 1). The lowest ratios were observed for strains of $R$. mucilaginosa from deep waters, Lecanicillium sp. and Fusarium sp. from coastal waters, and M. circinelloides from coastal sediments (Table 1). Carbon and nitrogen stable isotopic composition of fungal isolates averaged $-25.8 \pm 0.6 \%$ and $0.9 \pm$ $1.6 \%$, respectively (Table 1 ). Even though $\delta^{13} \mathrm{C}$ and $\delta^{15} \mathrm{~N}$ composition of isolates were on average comparable to those of the food source (dry culture medium, $\delta^{13} \mathrm{C}:-25.5 \%$ and $\delta^{15} \mathrm{~N}: 0.02 \%$ ), $R$. mucilaginosa and C. sphaerospermum showed fractionation of $3-5 \%$ for $\delta^{15} \mathrm{~N}$ (Table 1). Energetic content of isolates averaged $3.6 \pm 0.3 \mathrm{kcal} \mathrm{g}^{-1} \mathrm{dw}$, with the highest value observed in $R$. mucilaginosa (Table 1).

Although some variability in $\mathrm{C}$ and $\mathrm{N}$ content, $\mathrm{C} / \mathrm{N}$ ratio, and energetic content was observed across depths (surface, subsurface and deep) and geographic regions, no significant differences were detected (Mann-Whitney p > 0.05, see Fig. S1 in the Supplement at www.int-res.com/articles/suppl/a084 p075_supp.pdf). 


\subsection{Amino acids, fatty acids and sterols in culturable marine fungi}

Content of total hydrolysable amino acids (THAA) averaged $87.1 \pm 57.8 \mathrm{mg} \mathrm{g}^{-1} \mathrm{dw}$ (Table 1), accounting for $3 \%$ (C. sphaerospermum) to $21 \%$ (Lecanicillium sp.) of mycelial dry weight. Relative molar proportions of lysine, alanine, aspartic acid, glutamine, valine, leucine and threonine accounted for $\sim 60 \%$ of THAA (Fig. 3A).

Concentrations of fatty acid methyl ester (FAMEs) ranged from $<0.1$ to $3 \mathrm{mg} \mathrm{g}^{-1} \mathrm{dw}$ (Table 1 ), with max- imum values observed in Fusarium sp. isolated from subsurface waters off central Chile, and in Penicillium sp. isolated from surface waters of the coastal region off northern Chile (Table 1). Two individual

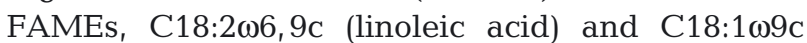
(oleic acid), accounted for $61 \%$ of FAMEs; together

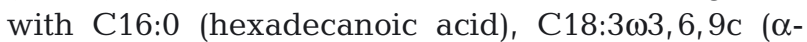
linolenic acid) and C18:0 (octadecanoic acid), they represented over $90 \%$ of FAMEs (Fig. 3B). Half of the detected FAMEs were polyunsaturated FAMEs (PUFA, 2 or more double bonds), with monounsaturated (MUFA) and saturated (SAT) compounds
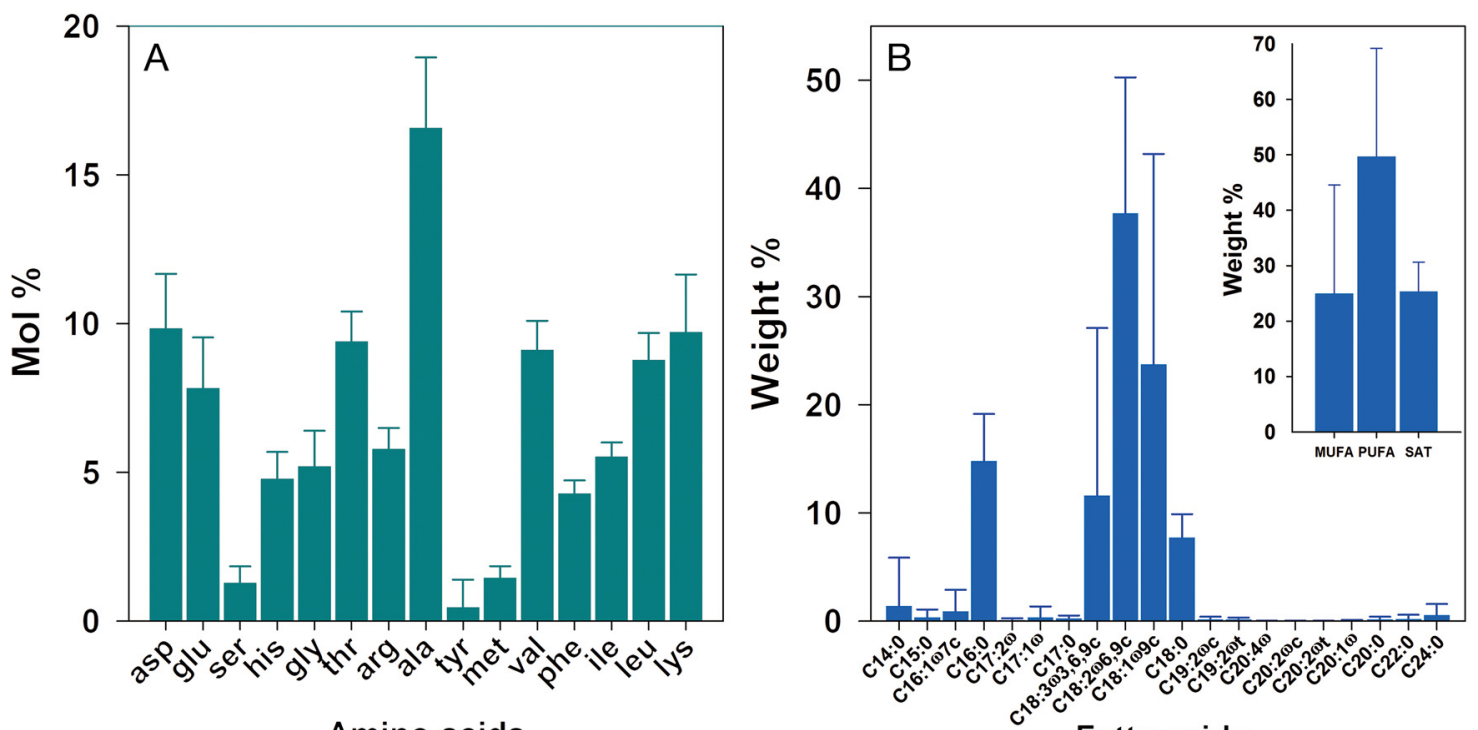

Amino acids
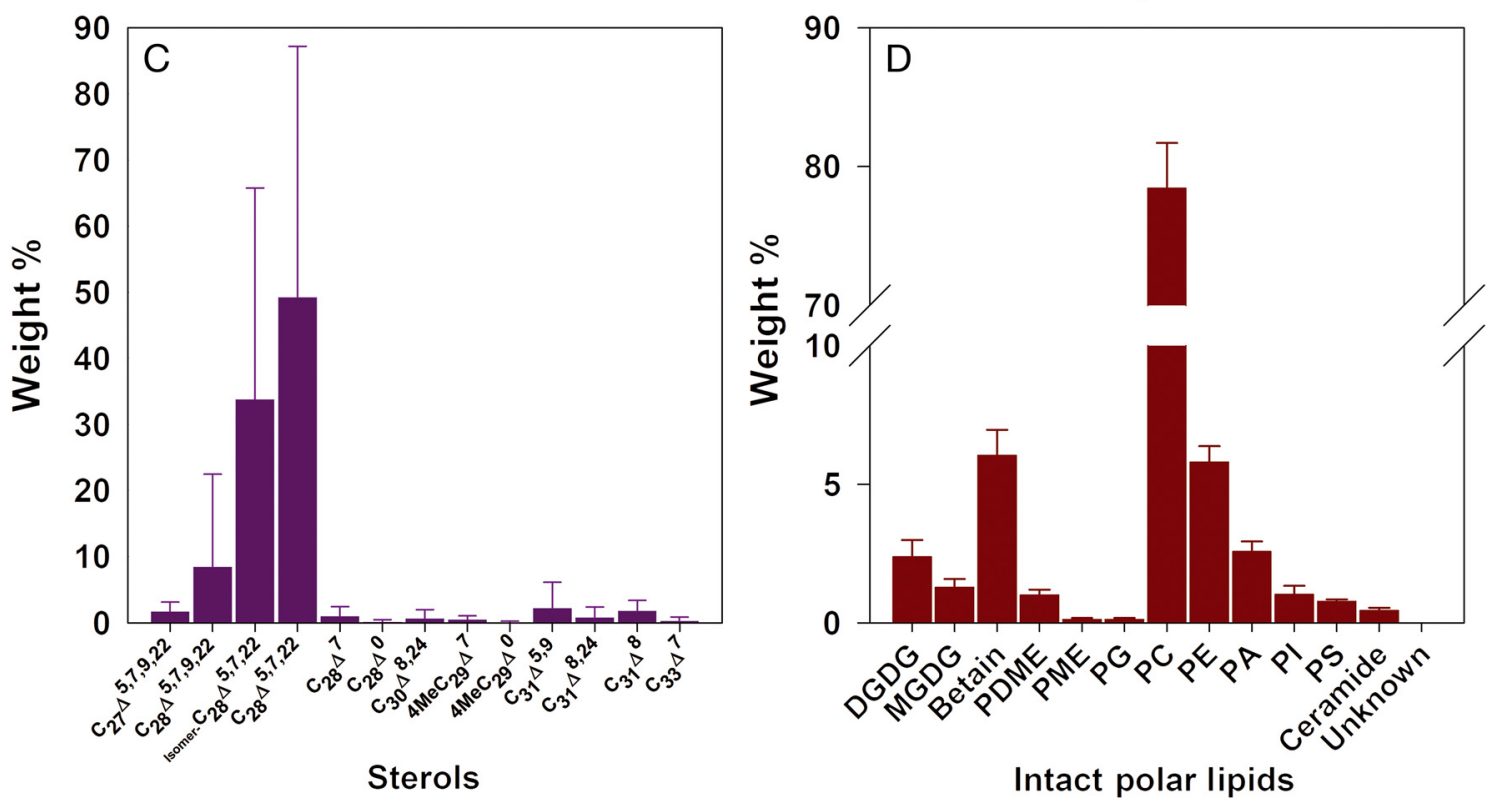

Fig. 3. Average molecular composition of (A) amino acids, (B) fatty acids, (C) sterols and (D) intact polar lipids in 13 marine fungal strains. Mol\% and weight\% refer to fraction of compound with respect to sum of all detected amino acids, fatty acids, sterols and intact polar lipids. Error bars represent $1 \mathrm{SD}$ 
accounting for $\sim 25 \%$ each (Fig. 3B). Sterol contents ranged from 10 to ca. $600 \mu \mathrm{g} \mathrm{g}^{-1} \mathrm{dw}$, with the higher values observed in strains isolated from waters and sediments off central Chile (Table 1, Site C in Fig. 1,). Most sterols were C-28 $(>90 \%)$, with ergosterol $\left(\mathrm{C}_{28} \Delta^{5,7,22}\right)$ and its isomer dehydrostellasterol (isomer- $\mathrm{C}_{28} \Delta^{5,7,22}$ ) accounting on average for $85 \%$ of sterols (Fig. 3C).

\subsection{Abundance and composition of intact polar lipids}

According to their headgroups, 4 main classes of IPLs were identified: (1) glycolipids, represented by monoglycosyldiacylglycerol (MGDG) and diglycosyldiacylglycerol (DGDG); (2) nitrogen bearing betaine diacylglyceryl-trimethyl-homoserine (DGTS) lipids; (3) glycerophospholipids, which included phosphatidyl-ethanolamine (PE), phosphatidyl-Nmethylethanolamine (PME), phosphatidyl-N-dimethylethanolamine (PDME), phosphatidyl-choline (PC), phosphatidic acid (PA), phosphatidyl-inositol (PI) phosphatidyl-glycerol (PG), and phosphatidylserine (PS); and (4) ceramide sphingolipids (Fig. 3D). The summed fatty acid chains of IPLs averaged 35 carbon atoms and contained up to 6 double bonds. IPL headgroups were dominated (ca. $95 \%$ ) by PC, PE, PA, betaine and DGDG.

IPL content ranged from 4 to $32 \mathrm{mg} \mathrm{g}^{-1} \mathrm{dw}$ across the fungal strains (Table 1), with PC accounting for $78 \%$ of IPLs, followed by $6 \%$ of each betaine-DGTS and PE (Fig. 3D). The highest IPL content was found in a Penicillium strain isolated from the coastal waters off northern Chile (Table 1, Site A in Fig. 1). Relative abundance of IPLs showed considerable variability between sampling regions, but no significant differences were detected (Mann-Whitney p $>0.05$, see Fig. S1C in the Supplement).

\section{DISCUSSION}

\subsection{Taxonomy of marine-derived fungi}

Of the 12 taxonomically identified isolates of marine fungi (Fig. 2) in the present study, 7 strains from the upwelling and fjord regions of the eastern South Pacific Ocean off Chile were identified as Penicillium brevicompactum, Penicillium sp., Lecanicillium sp., Fusarium sp., and Cladosporium sphaerospermum from the phylum Ascomycota. The phylum Zygomycota was represented by Mucor circinelloides, isolated from surface sediments off central Chile, and the phylum Basidiomycota by Rhodotorula mucilaginosa, along with an uncharacterized yeast (BR71), recovered from deep waters off Easter Island. Since strain BR71 is morphologically similar to BR74 (colored yeast $R$. mucilaginosa, Table 1), which was collected at $1000 \mathrm{~m}$ depth in the same sampling site and had similar contents of FAMEs, sterols, and IPLs, we classified it in the genus Rhodotorula, although we presently lack genomic information to confirm this classification.

Our results are consistent with previous findings showing wide representation of the genus Penicillium in isolates from waters of coastal and oceanic regions off Chile (Vera et al. 2017), and a high diversity of culturable (Vera et al. 2017) and ambient (Gutiérrez et al. 2017) taxa off the coast of central Chile, likely associated with the high degree of heterogeneity of this environment. Rhodotorula yeasts frequently appear in marine samples (e.g. Wirth \& Goldani 2012), and the filamentous fungus Lecanicillium sp. has been previously recovered from hydrothermal vents (Le Calvez et al. 2009). The genera Cladosporium and Mucor have been found in coastal environments, typically associated with marine sponges (Batista-García et al. 2017).

To date, published information on the diversity of marine fungi is scarce (e.g. Richards et al. 2012, Amend et al. 2019) and in our study area in the eastern South Pacific Ocean, prior studies have been restricted to the culturable ascomycetes (Vera et al. 2017) which cannot be considered representative of environmental diversity in this area. However, the selected strains in the present study did include several isolates identified as Penicillium sp., which were the predominant taxa in prior work (Vera et al. 2017).

\subsection{Elemental composition of and organic compounds in marine fungal mycelia}

The organic carbon and nitrogen contents that we measured for fungal mycelia were comparable with those of other planktonic organisms, although $\mathrm{C}$ to $\mathrm{N}$ molar ratios were almost double the typical Redfield ratios reported for marine plankton (Table 2). Organic carbon and energetic contents of fungal isolates varied little among taxonomic groups (coefficient of variation $<20 \%$ ), with relatively high carbon and caloric contents measured in unrelated taxa such as the basidiomycete Rhodotorula and the ascomycete Penicillium. Organic carbon contents for the marine fungi reported here are lower than those of fungi isolated from terrestrial environments (38-57\%, Zhang 
Table 2. Carbon, nitrogen and caloric content per gram dry weight (dw) for a wide range of pelagic marine organisms, and marine and terrestrial fungi

\begin{tabular}{|c|c|c|c|c|}
\hline $\begin{array}{l}\text { Group of } \\
\text { organisms }\end{array}$ & $\begin{array}{l}\text { Carbon } \\
(\% d w)\end{array}$ & $\begin{array}{l}\text { Nitrogen } \\
(\% d w)\end{array}$ & $\begin{array}{l}\text { Caloric content } \\
\left(\mathrm{kcal} \mathrm{g}^{-1} \mathrm{dw}\right)\end{array}$ & References \\
\hline Phytoplankton & $\begin{array}{c}34.1-50.8^{\mathrm{a}} \\
16.5-34.7\end{array}$ & $\begin{array}{c}4.6-6.9 \\
5.1-11.6^{\mathrm{a}} \\
1.1-6.3\end{array}$ & $\begin{array}{l}2.5-4.8 \\
2.1-3.7\end{array}$ & $\begin{array}{l}\text { Platt \& Irwin (1973), } \\
\text { Whyte (1987), } \\
\text { Peltomaa et al. (2017) }\end{array}$ \\
\hline Copepods & $25.9-67.5$ & $4.4-14.9$ & $5.6-7.2$ & Beers (1966), Omori (1969), \\
\hline Euphausiids/Mysiids & $34.8-54.0$ & $7.3-12.1$ & $0.9-6.0$ & Davis (1993), Ventura (2006), \\
\hline Chaetognatos & $21.9-47.7$ & $6.3-12.6$ & $1.2-6.7$ & Schaafsma et al. (2018) \\
\hline Fish/Fish Larvae & $32.6-46.5$ & $8.27-10.6$ & $3.3-9.3$ & \\
\hline Polychaetes & $15.9-43.9$ & $4.37-11.2$ & & \\
\hline Siphonophores & $3.0-16.0$ & $0.98-4.4$ & & \\
\hline Hydromedusae & $5.4-10.4$ & $1.34-6.9$ & & \\
\hline Pteropods & $17.0-29.0$ & $1.5-4.2$ & & \\
\hline Ctenophores & & & $0.7-3.5$ & \\
\hline Crustacean zooplankton & $42.5-64.2$ & $5.2-12.7$ & & Walve \& Larson (1999) \\
\hline Mixed net plankton & $14.0-21.5$ & $2.38-4.1$ & & Hedges et al. (2002) \\
\hline Mixed zooplankton & $\begin{array}{c}18.5-40.0 \\
25.5-44.9 \\
5.1-48.0\end{array}$ & $\begin{array}{l}2.4-9.4 \\
6.2-12.7 \\
1.1-10.4\end{array}$ & $1.37-4.2$ & $\begin{array}{l}\text { Goswami et al. (1981), } \\
\text { Ikeda \& McKinnon (2012), } \\
\text { Kiørboe (2013) }\end{array}$ \\
\hline Bacteria & $29.0-50.4$ & $4.0-12.9$ & $4.6-6.3^{\mathrm{b}}$ & $\begin{array}{l}\text { Prochazka et al. (1970), } \\
\text { Bratbak \& Dundas (1984), } \\
\text { Nagata (1986), Vrede et al. (2002) }\end{array}$ \\
\hline Terrestrial fungi & $38-57$ & $0.23-15$ & $3.6-5.7$ & $\begin{array}{l}\text { Gray \& Staff (1967), } \\
\text { Zhang \& Elser (2017) }\end{array}$ \\
\hline Marine fungi & $23.8 \pm 4.4$ & $2.6 \pm 1$ & 3.6 & This study \\
\hline
\end{tabular}

\& Elser 2017). In contrast, the nitrogen contents of these marine fungi were within the published range for terrestrial fungi (0.23-15\%, Zhang \& Elser 2017), with $R$. mucilaginosa and Lecanicillium sp. having the highest observed nitrogen content $(\geq 4 \%)$. Average elemental composition and energetic content of marine-derived fungi (Table 1) were within the published ranges for bacteria, phytoplankton, zooplankton and other metazoans from aquatic environments (Table 2). Caloric contents of marine fungi were lower than those of krill Euphausia pacifica and Thysanoessa inermis, and higher than those of zooplanktonic Cnidaria, Ctenophora, and Gastropoda (Table 2). Considering that biomass of filamentous fungi can be as high as that of prokaryotes in the coastal upwelling ecosystem off central Chile (Gutiérrez et al. 2011), we suggest that fungal mycelia can represent a sizable reservoir of extant carbon and nitrogen in the pelagic ecosystem. As such, marine fungi may play a significant role in organic carbon and nutrient mobilization in the ocean. Improvement of quantitative methods of de- tection and expansion of sampling coverage should reduce the current large uncertainty (e.g. Bar-On et al. 2018) in estimates of marine fungal biomass.

Elemental stoichiometry is not well constrained for marine fungi. Our data showed $\mathrm{C}$ to $\mathrm{N}$ molar ratios $(\mathrm{C} / \mathrm{N} \sim 12)$ lower than those of terrestrial fungi ( $\mathrm{C} / \mathrm{N} \sim 16$, Zhang \& Elser 2017) but within the ample range reported for fungi isolated from freshwater environments (C/N $\sim 7-31$, Danger et al. 2016). Our average $\mathrm{C} / \mathrm{N}$ values were almost double that of the Redfield ratio for marine plankton (Redfield 1958), but in isolates from 3 diverse environments (upwelling, coastal water and sediment, and deep oceanic waters) ratios approached the Redfield value ( $\mathrm{C} / \mathrm{N} \sim 8$, Table 1). Aquatic hyphomycete fungi are not homeostatic for elemental composition except under conditions of unlimited nutrient supply (Danger \& Chauvet 2013, Danger et al. 2016). Since $\mathrm{C} / \mathrm{N}$ ratios among our studied strains were rather homogeneous (coefficient of variation of $29 \%$ ) for replete culture conditions, we hypothesize that our $\mathrm{C} / \mathrm{N}$ values represented intrinsic properties 
of the analyzed strains. Observed variations in elemental composition of strains across depths and regions of collection may indicate a potential environmental effect; however, statistical analysis of a larger suite of strains would be required to further support this hypothesis. An understanding of the natural variability of elemental ratios among mycoplankton species would help in assessing the role of fungi in modification of $\mathrm{C} / \mathrm{N}$ ratios during diagenesis in the ocean; the Redfield ratio could increase or decrease depending on fungal contribution to microbial biomass and reworking of planktonic organic matter.

Analysis of the composition of individual organic molecules within mycelia indicated the presence of several essential amino acids, and the predominance of PUFAs, ergosterol in the sterol fraction, and phosphatydylcoline in the intact polar lipids fraction. On average, protein (as THAA) accounted for $9 \pm 6 \%$ of fungal mycelia, followed by intact polar lipids (including head group plus core fatty acids), which accounted for $1.3 \pm 0.7 \%$ of fungal biomass. Fatty acids accounted for $0.1 \pm 0.1 \%$ and sterols $0.02 \pm 0.02 \%$ of mycelial dry weight. THAA (protein) content of fungal mycelia (3-21\% mycelial dry weight) was lower than observed in plankton (20-40\%; Lee et al. 1988), freshwater zooplankton (>50\%; Dabrowski \& Rusiecki 1983), marine phytoplankton (12-35\%; Brown et al. 1991), marine zooplankton (4-55\%, Raymont et al. 1973), and marine bacteria ( 60\%; Simon \& Azam 1989). These results suggest that marine fungal proteins are generally less abundant than those from plankton. However, marine fungal strains were generally richer in the essential amino acids histidine, threonine, valine, lysine and leucine (Fig. 3A) than are soil fungi (Wallis et al. 2012), and may therefore represent a source of particular molecules critical to the diet of metazoans in the marine environment.

Hydrolyzable amino acids (protein) accounted for as low as $20 \%$ and as high as $78 \%$ of fungal nitrogen, indicating that up to $80 \%$ nitrogen (e.g. in C. sphaerospermum) is stored in other $\mathrm{N}$-containing molecules in fungal mycelia. Chitin, a principal polymer present in fungal cell walls (Latgé 2007), represents a large reservoir of carbon and nitrogen in the ocean (Souza et al. 2011) produced by crustaceans at a rate of ca. 2 million metric tons per year (Jeuniaux \& VossFoucart 1991). The cell walls of marine fungi could be an important previously unaccounted pool of chitin and particulate organic nitrogen in the marine environment, and thus may play an important role in nutrient cycling. In support of our hypothesis, fungal debris has been documented in sediment traps in association with sinking chitin fluxes in the subarctic Pacific Ocean (Montgomery et al. 1990).

Fatty acid composition showed a predominance of

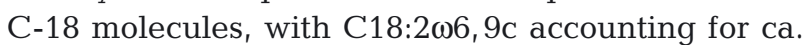
$38 \%$ and $\mathrm{C} 18: 1 \omega, 9 \mathrm{c}$ for $23 \%$ of fatty acids. Fatty acid $18: 2 \omega 6,9$ (linoleic acid) is consistently regarded to be a fungal marker in terrestrial environments (Vestal \& White 1989, Frostegård \& Bååth 1996, Boschker \& Middelburg 2002), and has also been reported as a major constituent (11-37\%) of fatty acids of marine fungi (Cooney et al. 1993, Devi et al. 2006, Das et al. 2007). Linoleic acid also covaries with the abundance of fungal filaments in the coastal upwelling ecosystem off Chile (Gutiérrez et al. 2011). PUFAs accounted for half of the fatty acids present, suggesting that together with other planktonic organisms, fungi can be an important source of nutritional lipids for pelagic organisms. In support of this contention, the proportion of PUFAs in marine-derived fungi (this study and Das et al. 2007) is within the upper range of values reported for marine phytoplankton (Lewis 1969, Zhukova \& Aizdaicher 1995, Arendt et al. 2005), zooplankton (Najdek 1997, Escribano \& Perez 2010), and bacteria (Russell \& Nichols 1999, Das et al. 2007).

Ergosterol, and its isomer dehydrostellasterol $\left(C_{28} \Delta^{5,7,22}\right)$, were the dominant sterols in all the marine fungal strains analyzed, and this observation is consistent with their known predominance in most terrestrial ascomycetes and basidiomycetes (Weete et al. 2010). Ergosterol has been used to estimate fungal biomass in soils (Montgomery et al. 2000, Joergensen \& Wichern 2008), rivers (Joergensen \& Wichern 2008), salt and freshwater marshes (Newell et al. 2000, Buesing \& Gessner 2006), and wetlands (Verma et al. 2003). Ergosterol accounts for more than $80 \%$ of sterols in all fungal strains and is the predominant sterol in membranes of Dikarya (Weete et al. 2010), which includes most of the fungi identified in marine environments (Amend et al. 2019). We therefore suggest that ambient ergosterol concentrations in particulate organic matter could be an appropriate proxy for a major fraction of extant fungi biomass in the ocean. Indeed, ambient concentrations of ergosterol were recently used to estimate fungal biomass in Arctic waters (Hassett et al. 2019). Since ergosterol is not present in basal lineages of fungi such as chytridiomycetes, which have been shown to be abundant in some marine environments (Gutiérrez et al. 2016, Hassett et al. 2019), specific biomarkers of different groups will be required for a better assessment of actual contribu- 
tion of marine fungi to microbial biomass in the ocean.

Consistent with being a major phospholipid of cell membranes, phosphatidylcholine (PC) was the dominant IPL in marine-derived fungi. Phospholipids, particularly PC, appear to be beneficial in the diet of several species of freshwater and marine fish and crustaceans, improving survival, growth, and resistance to stress (Coutteau et al. 1997, 2000, Wang et al. 2016). Phospholipids are also utilized as storage lipids in some species of marine zooplankton (Hagen \& Schnack-Schiel 1996, Lee et al. 2006). With biomass of marine fungi potentially being as high as that of prokaryotes in the coastal ocean (Gutiérrez et al. 2011), we suggest that marinefungi-derived phospholipids could be a significant nutritional complement in the diet of marine organisms. Indeed, the content of PC in our fungal strains (Table 1) is comparable to that reported for microalgae (Cañavate et al. 2016). If proven, such a role for PC in the ocean would provide a nutritional dimension for studying IPLs in addition to their taxonomic importance (Sturt et al. 2004, Cañavate et al. 2016) and environmentally driven variability (Van Mooy et al. 2009, Sebastián et al. 2016). Marine fungi certainly need to be considered when interpreting water column IPL signatures, and assigning potential taxonomic sources to PC (e.g. Schubotz et al. 2018).

\subsection{Biochemical signature of fungi in the marine ecosystem}

The composition of marine organic matter is determined by the accumulation of organic components from a variety of biological sources. Recognizing patterns of individual components of autochthonous and allochthonous organic matter is key to understanding their contribution to biogeochemical cycling, and to tracing their fate and trophic interactions in marine ecosystems. The amino acid and fatty acid composition of marine-derived fungi clearly differs from that of prokaryotes, phytoplankton, zooplankton, and fish, with lysine, histidine, threonine, alanine, and mono- and di-unsaturated C18 fatty acids being particularly useful compounds for differentiating among groups (Fig. 4).

In order to understand fractionation by marine fungi during heterotrophic growth, and to identify potential diagnostic signals for geochemical studies in the ocean, we compared carbon and nitrogen stable isotope composition of the growth substrate with that of the resulting fungal biomass. Adopting the general scheme of Meyers (1994), the pattern of marine-fungi-derived $\mathrm{C} / \mathrm{N}$ and $\delta^{13} \mathrm{C}$ (Fig. 5) is consistent with a heterotrophic role proposed for fungi as degraders of planktonic detritus in the coastal ocean (Gutiérrez et al. 2011, Cunliffe et al. 2017). However, these results should be interpreted with caution since
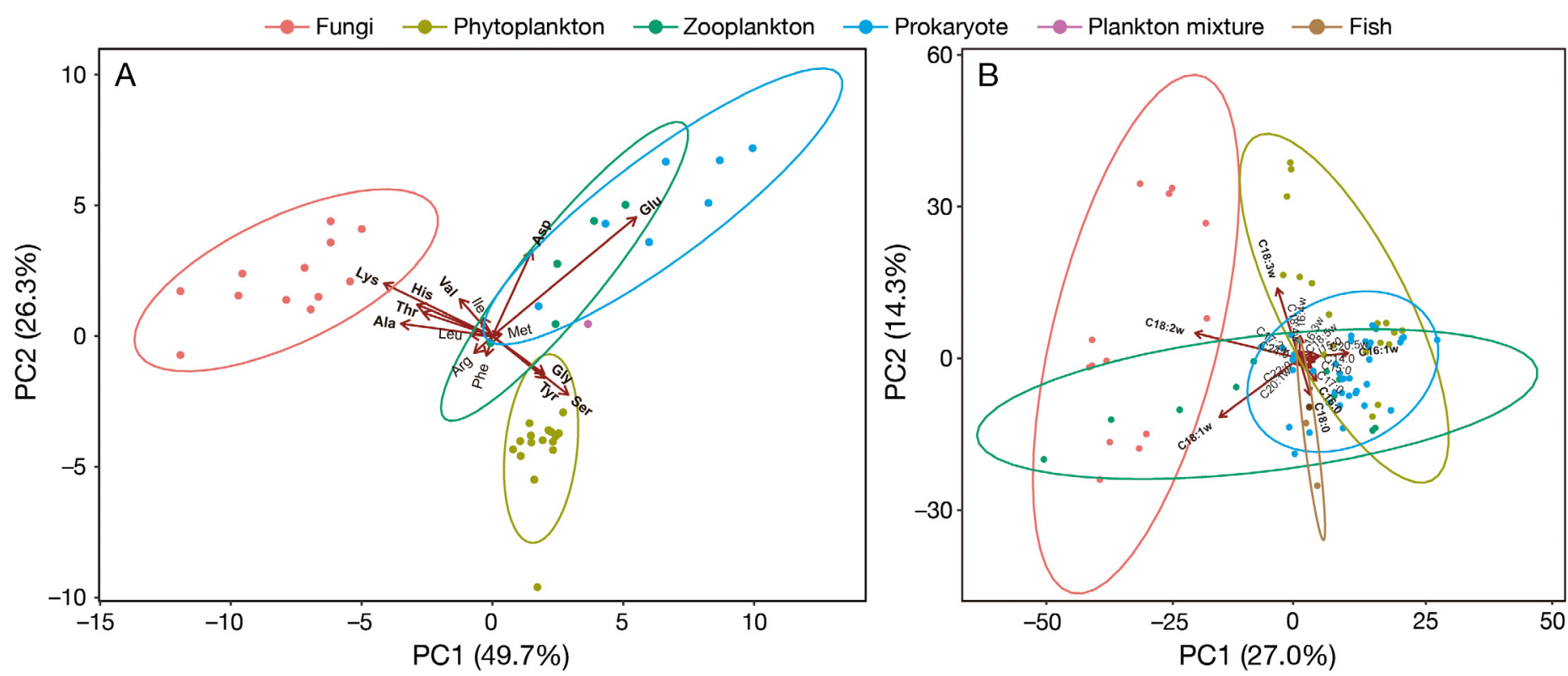

Fig. 4. Principal component analysis comparing the specific signatures of (A) amino acids and (B) fatty acids of marine-derived fungi with those of other pelagic organisms (Chuecas \& Riley 1969, Lewis 1969, Jeffries 1970, Raymont et al. 1973, Taylor \& Parkes 1983, Lee et al. 1988, Simon \& Azam 1989, Brown et al. 1991, Nichols et al. 1993, Zhukova \& Aizdaicher 1995, Russell \& Nichols 1999, Oren \& Mana 2002, Das et al. 2007, Escribano \& Perez 2010, Medina et al. 2014, Wang et al. 2017). Arrows indicate amino acids and fatty acids that explain singular signatures of each group 


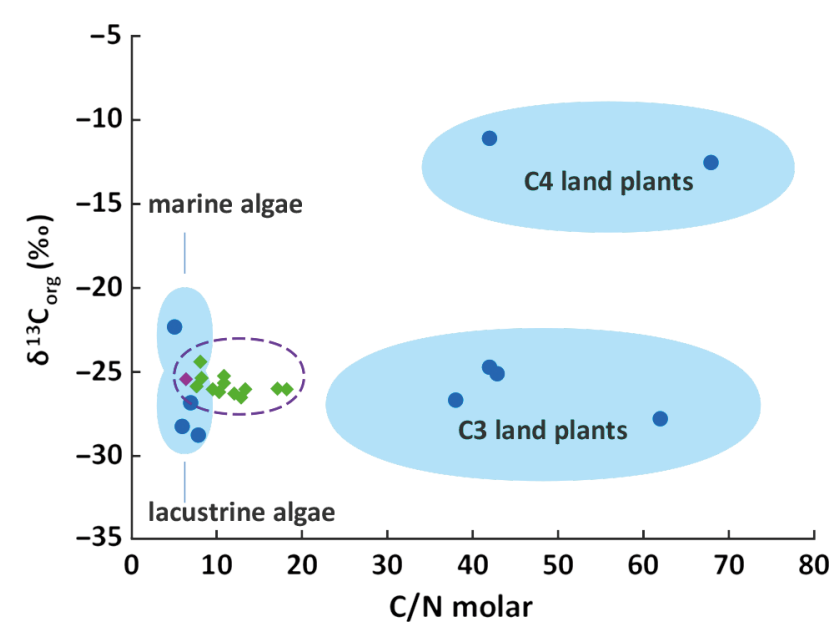

Fig. 5. Stoichiometric and stable isotopic composition of carbon and nitrogen of marine fungi (green diamonds) and dry culture medium (purple diamond) in the framework of Meyers' classification of terrestrial and marine organic matter (blue circles and light blue ovals) taken from Table 1 of Meyers (1994). $\delta^{13} \mathrm{C}$ and $\mathrm{C} / \mathrm{N}$ data for marine fungal strains are enclosed in a purple dashed oval

$\delta^{13} \mathrm{C}$ and $\delta^{15} \mathrm{~N}$ are determined by the substrate for fungal growth. Substrate organic matter in the culture medium had characteristic terrestrial $\delta^{13} \mathrm{C}$ and $\delta^{15} \mathrm{~N}$ values $\left(\delta^{13} \mathrm{C}:-25.5 \%\right.$, $\delta^{15} \mathrm{~N}: 0.02 \%$, while its elemental composition (C/N: 6.5) resembled that of marine particulate organic matter (6.6, Martiny et al. 2014). Two out of the 12 strains showed fractionation of 3 and $5 \%$ between $\delta^{15} \mathrm{~N}$-biomass and source $\mathrm{N}$ $(0.02 \%$, Table 1$)$, as also shown for freshwater fungi, varying by 3.6 to $5.9 \%$ with respect to bulk $\mathrm{N}$ litter (Costantini et al. 2014). Such fractionation is also similar to the range of 2-4\% reported for enrichment of consumers (Deniro \& Epstein 1981, Minagawa \& Wada 1984) and the $3 \%$ reported in the pelagic marine environment (Checkley \& Miller 1989, Montoya et al. 2002). For freshwater (Costantini et al. 2014) and ectomycorrhizal fungi (Hobbie \& Högberg 2012), the extent of $\mathrm{N}$ isotope fractionation is strain-dependent and appears to be associated with metabolic capabilities and utilization of different forms of organic matter. Defining the stable isotope signatures of marine fungi is a novel avenue for future research that should help to explain the stable isotope fractionation of organic molecules in the ocean.

A central role of fungi in terrestrial and aquatic marsh-type ecosystems is their action as saprotrophs on detrital organic matter (Hyde et al. 1998, Raghukumar 2005). Marine detritus includes a component of reworked organic matter with lower nutritional values than extant biomass (e.g. Dauwe et al. 1999), which is not available for direct use and transfer through the marine trophic web (Mann 1988, Lopez \& Levinton 2011). Our data on organic and elemental composition of selected strains suggest that marine fungi are rich in essential molecules, have a relatively high energetic content, and have lower $\mathrm{C}$ to $\mathrm{N}$ molar ratios than marine algae. Thus, as recognized modifiers of organic detritus in some coastal environments (Hyde et al. 1998, Newell et al. 2000, Raghukumar 2005), fungi are a potential conduit for repackaging refractory or low nutritious organics into fresh biomass rich in nutritive molecules available for transfer through the marine trophic web. This role is equivalent to the action of parasitic fungi on diatoms in freshwater ecosystems, where chytrids infect inedible phytoplankton and release flagellated zoospores rich in nutritive molecules that can positively impact the diet of zooplankton (Kagami et al. 2011). Thus, through their variety of roles in the marine ecosystem (Gutiérrez et al. 2011, 2016, Cunliffe et al. 2017, Amend et al. 2019), fungi can potentially provide otherwise inaccessible 'fuel' for trophic webs in the ocean. Our study provides evidence for $\mathrm{C} / \mathrm{N}$ molar ratios in the upper range of those of marine algae, but lower than the range for terrestrial organic matter (Fig. 5). Occurrence and activity of fungi can clearly impact the C/N ratios of organic matter, potentially leading to misinterpretation of source of organic matter in detrital and sedimentary environments. Detailed consideration of lipid fingerprints of marine fungi could help to elucidate their relative contribution in environments with mixed sources of organic matter.

In conclusion, our findings suggest that marine fungi play a hitherto underestimated role in carbon and nutrient cycling in the ocean, and that their nutritional value is comparable to that of other planktonic organisms. We have also demonstrated that marine fungi have a distinctive pattern of lipids and proteins, and that their elemental composition is consistent with a marine source and heterotrophic uptake of phytoplankton-derived organic matter. These findings open new perspectives for the detection and study of marine fungi, and for a better understanding of the contribution of fungi to microbial biomass and the cycling of carbon and nutrients in the ocean.

Acknowledgements. This research was funded by COPAS Sur-Austral CONICYT PIA APOYO CCTE AFB170006 with the support of the Hanse-Wissenschaftskolleg (Hanse Institute for Advanced Studies), Delmenhorst, Germany. R.A.Q. received funding from the Interdisciplinary Center for Aquaculture Research (INCAR, FONDAP 15110027). We also thank Marcelo Fuentes, Julius Lipp, Lilian Núñez and Xavier Prieto-Mollar for analytical help, and Dr. David Crawford for valuable comments. 


\section{LITERATURE CITED}

Alfaro M, Holder M (2006) The posterior and the prior in Bayesian phylogenetics. Annu Rev Ecol Evol Syst 37: 19-42

Amend A, Burgaud G, Cunliffe M, Edgcomb VP and others (2019) Fungi in the marine environment: open questions and unsolved problems. MBio 10:1-15

Arendt KE, Jónasdóttir SH, Hansen PJ, Gärtner S (2005) Effects of dietary fatty acids on the reproductive success of the calanoid copepod Temora longicornis. Mar Biol 146:513-530

Azam F (1998) Microbial control of oceanic carbon flux: the plot thickens. Science 280:694-696

Azam F, Malfatti F (2007) Microbial structuring of marine ecosystems. Nat Rev Microbiol 5:782-791

Bar-On YM, Phillips R, Milo R (2018) The biomass distribution on Earth. Proc Natl Acad Sci USA 115:6506-6511

Batista-García RA, Sutton T, Jackson SA, Tovar-Herrera OE and others (2017) Characterization of lignocellulolytic activities from fungi isolated from the deep-sea sponge Stelletta normani. PLOS ONE 12:e0173750

Beers JR (1966) Studies on the chemical composition of the major zooplankton groups in the Sargasso Sea off Bermuda. Limnol Oceanogr 11:520-528

Bligh EG, Dyer WJ (1959) A rapid method of total lipid extraction and purification. Can J Biochem Physiol 37: 911-917

Bochdansky AB, Clouse MA, Herndl GJ (2016) Dragon kings of the deep sea: marine particles deviate markedly from the common number-size spectrum. Sci Rep 6:22633

Boschker HTS, Middelburg JJ (2002) Stable isotopes and biomarkers in microbial ecology. FEMS Microbiol Ecol 40:85-95

Bratbak G, Dundas I (1984) Bacterial dry matter content and biomass estimations. Appl Environ Microbiol 48:755-757

Brown PC, Painting SJ, Cochrane KL (1991) Estimates of phytoplankton and bacterial biomass and production in the northern and southern Benguela ecosystems. S Afr J Mar Sci 11:537-564

Buesing N, Gessner MO (2006) Benthic bacterial and fungal productivity and carbon turnover in a freshwater marsh. Appl Environ Microbiol 72:596-605

Burgaud G, Woehlke S, Rédou V, Orsi W and others (2013) Deciphering the presence and activity of fungal communities in marine sediments using a model estuarine system. Aquat Microb Ecol 70:45-62

Cañavate JP, Armada I, Riós JL, Hachero-Cruzado I (2016) Exploring occurrence and molecular diversity of betaine lipids across taxonomy of marine microalgae. Phytochemistry 124:68-78

Checkley DM, Miller CA (1989) Nitrogen isotope fractionation by oceanic zooplankton. Deep-Sea Res A, Oceanogr Res Pap 36:1449-1456

* Christie WW (1998) Gas chromatography-mass spectrometry methods for structural analysis of fatty acids. Lipids 33:343-353

Chuecas BL, Riley JP (1969) Component fatty acids of the total lipids of some marine phytoplankton. J Mar Biol Assoc UK 49:97-116

* Cooney JJ, Doolittle MM, Grahl-Nielsen O, Haaland IM, Kirk PWJ (1993) Comparison of fatty acids of marine fungi using multivariate statistical analysis. J Ind Microbiol 12:373-374

Costantini ML, Calizza E, Rossi L (2014) Stable isotope vari- ation during fungal colonisation of leaf detritus in aquatic environments. Fungal Ecol 11:154-163

Coutteau P, Geurden I, Camara MR, Bergot P, Sorgeloos P (1997) Review on the dietary effects of phospholopids in fish and crustacean larviculture. Aquaculture 155: 149-164

Coutteau P, Kontara EKM, Sorgeloos P (2000) Comparison of phosphatidylcholine purified from soybean and marine fish roe in the diet of postlarval Penaeus vannamei boone. Aquaculture 181:331-345

Crowther TW, Boddy L, Jones TH (2012) Functional and ecological consequences of saprotrophic fungus-grazer interactions. ISME J 6:1992-2001

Cunliffe M, Hollingsworth A, Bain C, Sharma V, Taylor JD (2017) Algal polysaccharide utilisation by saprotrophic planktonic marine fungi. Fungal Ecol 30:135-138

*Dabrowski K, Rusiecki M (1983) Content of total and free amino acids in zooplanktonic food of fish larvae. Aquaculture 30:31-42

* Daneri G, Dellarossa V, Quiñones R, Jacob B, Montero P, Ulloa O (2000) Primary production and community respiration in the Humboldt Current system off Chile and associated oceanic areas. Mar Ecol Prog Ser 197: 41-49

* Danger M, Chauvet E (2013) Elemental composition and degree of homeostasis of fungi: are aquatic hyphomycetes more like metazoans, bacteria or plants? Fungal Ecol 6:453-457

Danger M, Gessner MO, Barlocher FB (2016) Ecological stoichiometry of aquatic fungi: current knowledge and perspectives. Fungal Ecol 19:100-111

Das S, Lyla PS, Khan SA (2007) Fatty acid profiles of marine benthic microorganisms isolated from the continental slope of Bay of Bengal: a possible implications in the benthic food web. Ocean Sci J 42:247-254

* Dauwe B, Middelburg JJ, Herman PMJ, Heip CHR (1999) Linking diagenetic alteration of amino acids and bulk organic matter reactivity. Limnol Oceanogr 44: 1809-1814

Dávila P, Figueroa D, Müller E (2002) Freshwater input into the coastal ocean and its relation with the salinity distribution off austral Chile $\left(35-55^{\circ} \mathrm{S}\right)$. Cont Shelf Res 22: 521-534

Davis ND (1993) Caloric content of oceanic zooplankton and fishes for studies of salmonid food habits and their ecologically related species. (NPAFC Doc) FRI-UW-9312 Fisheries Research Institute, University of Washington, Seattle, WA

Deniro MJ, Epstein S (1981) Influence of diet on the distribution of nitrogen isotopes in animals. Geochim Cosmochim Acta 45:341-351

Devi P, Shridhar MPD, Souza LD, Naik CG (2006) Cellular fatty acid composition of marine-derived fungi. Indian $\mathrm{J}$ Geo-Mar Sci 35:359-363

E Escribano R, Perez C (2010) Variability in fatty acids of two marine copepods upon changing food supply in the coastal upwelling zone off Chile: importance of the picoplankton and nanoplankton fractions. J Mar Biol Assoc UK 90:301-313

FFalkowski PG, Fenchel T, Delong EF (2008) The microbial engines that drive Earth's biogeochemical cycles. Science 320:1034-1039

Feeney MJ, Dwyer J, Hasler-lewis CM, Milner JA and others (2014) Mushrooms and health summit proceedings. J Nutr 144:1128S-1136S 
Frostegård A, Bååth E (1996) The use of phospholipid fatty acid analysis to estimate bacterial and fungal biomass in soil. Biol Fertil Soils 22:59-60

Fuentes M, Quiñones RA, Gutiérrez MH, Pantoja S (2015) Effects of temperature and glucose concentration on the growth and respiration of fungal species isolated from a highly productive coastal upwelling ecosystem. Fungal Ecol 13:135-149

Gadd G (2006) Fungi in biogeochemical cycles. Cambridge University Press, New York, NY

Gao Z, Li B, Zheng C, Wang G (2008) Molecular detection of fungal communities in the Hawaiian marine sponges Suberites zeteki and Mycale armata. Appl Environ Microbiol 74:6091-6101

Gardes M, Bruns TD (1993) ITS primers with enhanced specificity for basidiomycetes, application to the identification of mycorrihiza and rusts. Mol Ecol 2:113-118

Goswami S, Rao T, Matondkar S (1981) Biochemical composition of zooplankton from the Andaman Sea. Indian J Geo-Mar Sci 10:296-300

Gray WD, Staff IA (1967) Fungal protein for food and feeds. VII. Caloric values of fungus mycelium. Econ Bot 21: 341-344

Grossart HP, Van den Wyngaert S, Kagami M, Wurzbacher C, Cunliffe M, Rojas-Jimenez K (2019) Fungi in aquatic ecosystems. Nat Rev Microbiol 17:339-354

*Guindon S, Dufayard JF, Lefort V, Anisimova M, Hordijk W, Gascuel O (2010) New algorithms and methods to estimate maximum-likelihood phylogenies: assessing the performance of PhyML 3.0. Syst Biol 59:307-321

Gutiérrez MH, Pantoja S, Quiñones RA, Gonzalez R (2010) First record of filamentous fungi in the coastal upwelling ecosystem off central Chile. Gayana (Concepc) 74:66-73

Gutiérrez MH, Pantoja S, Tejos E, Quiñones RA (2011) The role of fungi in processing marine organic matter in the upwelling ecosystem off Chile. Mar Biol 158:205-219

Gutiérrez MH, Galand PE, Moffat C, Pantoja S (2015) Melting glacier impacts community structure of Bacteria, Archaea and Fungi in a Chilean Patagonia fjord. Environ Microbiol 17:3882-3897

* Gutiérrez MH, Jara AM, Pantoja S (2016) Fungal parasites infect marine diatoms in the upwelling ecosystem of the Humboldt Current system off central Chile. Environ Microbiol 18:1646-1653

* Gutiérrez MH, Garcés DV, Pantoja S, González R, Quiñones RA (2017) Environmental fungal diversity in the upwelling ecosystem off central Chile and potential contribution to enzymatic hydrolysis of macromolecules in coastal ecotones. Fungal Ecol 29:90-95

Gutiérrez MH, Narváez D, Daneri G, Montero P (2018) Linking seasonal reduction of microbial diversity to increase in winter temperature of waters of a Chilean Patagonia fjord. Front Mar Sci 5:1-20

Hagen W, Schnack-Schiel S (1996) Seasonal lipid dynamics in dominant Antarctic copepods: energy for overwintering or reproduction? Deep Sea Res I 43:139-158

Hassett BT, Borrego EJ, Vonnahme TR, Rämä T, Kolomiets MV, Gradinger R (2019) Arctic marine fungi: biomass, functional genes, and putative ecological roles. ISME J 13:1484-1496

* Hedges JI, Baldock JA, Gélinas Y, Lee C, Peterson ML, Wakeham SG (2002) The biochemical and elemental compositions of marine plankton: a NMR perspective. Mar Chem 78:47-63

* Hobbie EA, Högberg P (2012) Nitrogen isotopes link mycor- rhizal fungi and plants to nitrogen dynamics. New Phytol 196:367-382

* Houbraken J, Frisva J, Samson R (2011) Taxonomy of Penicillium section Citrina. Stud Mycol 70:53-138

*Hyde KD, Jones EBG, Leaño E, Pointing SB, Poonyth AD, Vrijmoed LLP (1998) Role of fungi in marine ecosystems. Biodivers Conserv 7:1147-1161

* Ikeda T, McKinnon AD (2012) Metabolism and chemical composition of zooplankton and hyperbenthos from the Great Barrier Reef waters, North Queensland, Australia. Plankton Benthos Res 7:8-19

Jeffries HP (1970) Seasonal composition of temperate plankton communities: fatty acids. Limnol Oceanogr 15: 419-426

Jephcott TG, Van Ogtrop FF, Gleason FH, Macarthur DJ, Scholz B (2017) The ecology of chytrid and aphelid parasites of phytoplankton. In: Dighton J, White JF, Oudemans P (eds) The fungal community. CRC Press, Boca Raton, FL, p 239-256

Jeuniaux C, Voss-Foucart MFO (1991) Chitin biomass and production in the marine environment. Biochem Syst Ecol 19:347-356

Joergensen RG, Wichern F (2008) Quantitative assessment of the fungal contribution to microbial tissue in soil. Soil Biol Biochem 40:2977-2991

Johnson TW, Sparrow FK (1961) Fungi in oceans and estuaries. J Cramer, Weinheim

Kagami M, Helmsing NR, Van Donk E (2011) Parasitic chytrids could promote copepod survival by mediating material transfer from inedible diatoms. Hydrobiologia 659:49-54

Kagami M, Miki T, Takimoto G (2014) Mycoloop: chytrids in aquatic food webs. Front Microbiol 5:166

Kiørboe T (2013) Zooplankton body composition. Limnol Oceanogr 58:1843-1850

Kohlmeyer J, Kohlmeyer E (1979) Marine mycology: the higher fungi. Academic Press, New York, NY

Kurtzman CP, Robnett CJ (1998) Identification and phylogeny of ascomycetous yeasts from analysis of nuclear large subunit (26S) ribosomal DNA partial sequences. Ant Leeuwenhoek 73:331-371

Latgé JP (2007) The cell wall: a carbohydrate armour for the fungal cell. Mol Microbiol 66:279-290

* Le Calvez T, Burgaud G, Mahé S, Barbier G, Vandenkoornhuyse P (2009) Fungal diversity in deep-sea hydrothermal ecosystems. Appl Environ Microbiol 75:6415-6421

* Lee C, Wakeham SG, Hedges JI (1988) The measurement of oceanic particle flux-are 'swimmers' a problem? Oceanography (Wash DC) 1:34-36

* Lee RF, Hagen W, Kattner G (2006) Lipid storage in marine zooplankton. Mar Ecol Prog Ser 307:273-306

Lewis RW (1969) The fatty acid composition of arctic marine phytoplankton and zooplankton with special reference to minor acids. Limnol Oceanogr 14:35-40

* Lindroth P, Mopper K (1979) High performance liquid chromatographic determination of subpicomole amounts of amino acids by precolumn fluorescence derivatization with o-phthaldialdehyde. Anal Chem 51:1667-1674

Lopez GR, Levinton JS (2011) Particulate organic detritus and detritus feeders in coastal food webs. In: Wolanski E, McLusky D (eds) Treatise on estuarine and coastal science. Elsevier, Amsterdam, p 5-21

Mann KH (1988) Production and use of detritus in various freshwater, estuarine, and coastal marine ecosystems. Limnol Oceanogr 33:910-930 
Martiny AC, Vrugt JA, Lomas MW (2014) Concentrations and ratios of particulate organic carbon, nitrogen, and phosphorus in the global ocean. Sci Data 1:140048

Medina G, Castro L, Pantoja S (2014) Fatty acids in Merluccius australis tissues, a comparison between females from inshore and offshore spawning areas in the Chilean Patagonia. Fish Res 160:41-49

Méjanelle L, Laureillard J (2008) Lipid biomarker record in surface sediments at three sites of contrasting productivity in the tropical North Eastern Atlantic. Mar Chem 108: $59-76$

* Meyers P (1994) Preservation of elemental and isotopic source identification of sedimentary organic matter. Chem Geol 114:289-302

Minagawa M, Wada E (1984) Stepwise enrichment of ${ }^{15} \mathrm{~N}$ along food chains: further evidence and the relation between $\delta^{15} \mathrm{~N}$ and animal age. Geochim Cosmochim Acta 48:1135-1140

Montgomery HJ, Monreal CM, Young JC, Seifert KA (2000) Determinination of soil fungal biomass from soil ergosterol analyses. Soil Biol Biochem 32:1207-1217

* Montgomery MT, Nicholas A, David L (1990) A simple assay for chitin: application to sediment trap samples from the subarctic Pacific. Mar Ecol Prog Ser 64:301-308

Montoya JP, Carpenter EJ, Capone DG (2002) Nitrogen fixation and nitrogen isotope abundances in zooplankton of the oligotrophic North Atlantic. Limnol Oceanogr 47: 1617-1628

Murphy WJ, Eizirik E, O'Brien SJ, Madsen O and others (2001) Resolution of the early placental mammal radiation using Bayesian phylogenetics. Science 294: 2348-2351

Nagata T (1986) Carbon and nitrogen content of natural planktonic bacteria. Appl Environ Microbiol 52:28-32

* Najdek M (1997) Unusual changes of zooplankton fatty acid composition in the northern Adriatic during the 1991 mucilage event. Mar Ecol Prog Ser 159:143-150

Newell SY, Blum LK, Crawford RE, Dai T, Dionne M (2000) Autumnal biomass and potential productivity of salt marsh fungi from $29^{\circ}$ to $43^{\circ}$ north latitude along the United States Atlantic coast. Appl Environ Microbiol 66: 180-185

Nichols DS, Nichols PD, Mcmeekin TA (1993) Polyunsaturated fatty acids in Antarctic bacteria. Antarct Sci 5: $149-160$

* Omori M (1969) Weight and chemical composition of some important oceanic zooplankton in the North Pacific Ocean. Mar Biol 3:4-10

Oren A, Mana L (2002) Amino acid composition of bulk protein and salt relationships of selected enzymes of Salinibacter ruber, an extremely halophilic bacterium. Extremophiles 6:217-223

* Overy DP, Bayman P, Kerr RG, Bills GF (2014) An assessment of natural product discovery from marine (sensu strictu) and marine-derived fungi. Mycology 5:145-167

Pantoja S, Iriarte L, Daneri G (2011) Oceanography of the Chilean Patagonia. Cont Shelf Res 31:149-153

Peltomaa ET, Aalto SL, Vuorio KM, Taipale SJ (2017) The importance of phytoplankton biomolecule availability for secondary production. Front Ecol Evol 5:128

* Platt T, Irwin B (1973) Caloric content of phytoplankton. Limnol Oceanogr 18:306-310

Pomeroy LR (1974) The ocean's food web, a changing paradigm. Bioscience 24:499-504

*Pochazka GJ, Payne WJ, Mayberry WR (1970) Calorific content of certain bacteria and fungi. J Bacteriol 104: 646-649

Quiñones RA, Levipan H, Urritia H (2009) Spatial and temporal variability of planktonic archaeal abundance in the Humboldt Current system off Chile. Deep Sea Res II 56: 1073-1082

Quiñones R, Gutiérrez M, Daneri G, Gutiérrez D, González H, Chávez F (2010) Pelagic carbon fluxes in the Humboldt Current system. In: Liu K, Atkinson L, Quiñones A, Talaue-McManus L (eds) Carbon and nutrient fluxes in global continental margins: a global synthesis. SpringerVerlag, New York, NY, p 44-65

R Core Team (2018) R: a language and environment for statistical computing. R Foundation for Statistical Computing, Vienna. www.R-project.org

Raghukumar S (2002) Ecology of the marine protists, the Labyrinthulomycetes (Thraustochytrids and Labyrinthulids). Eur J Protistol 38:127-145

Raghukumar S (2005) The role of fungi in marine detrital processes. In: Ramaiah $\mathrm{N}$ (ed) Marine microbiology: facets \& opportunities. National Institute of Oceanography, Goa, p 91-101

Raymont JEG, Ferguson CF, Raymont JKB (1973) Biogeochemical studies on marine zooplankton. XL. The amino acid composition of some local species. Spec Publ Mar Biol Assoc India 60:91-99

Redfield AC (1958) The biological control of chemical factors in the environment. Am Sci 46:205-221

Richards TA, Jones MDM, Leonard G, Bass D (2012) Marine fungi: their ecology and molecular diversity. Annu Rev Mar Sci 4:495-522

* Ronquist F, Teslenko M, Van Der Mark P, Ayres DL and others (2012) Mrbayes 3.2: efficient Bayesian phylogenetic inference and model choice across a large model space. Syst Biol 61:539-542

Russell NJ, Nichols DS (1999) Polyunsaturated fatty acids in marine bacteria - a dogma rewritten. Microbiology 145: 767-779

* Schaafsma FL, Cherel Y, Flores H, van Franeker JA, Lea MA, Raymond B, van de Putte AP (2018) Review: the energetic value of zooplankton and nekton species of the Southern Ocean. Mar Biol 165:129

Schubotz F, Xie S, Lipp JS, Hinrichs KU, Wakeham SG (2018) Intact polar lipids in the water column of the eastern tropical North Pacific: abundance and structural variety of non-phosphorus lipids. Biogeosciences 15: 6481-6501

* Sebastián M, Smith AF, González JM, Fredricks HF and others (2016) Lipid remodelling is a widespread strategy in marine heterotrophic bacteria upon phosphorus deficiency. ISME J 10:968-978

Simon M, Azam F (1989) Protein content and protein synthesis rates of planktonic marine bacteria. Mar Ecol Prog Ser 51:201-213

* Souza CP, Almeida BC, Colwell RR, Rivera ING (2011) The Importance of chitin in the marine environment. Mar Biotechnol (NY) 13:823-830

* Sturt HF, Summons RE, Smith K, Elvert M, Hinrichs KU (2004) Intact polar membrane lipids in prokaryotes and sediments deciphered by high-performance liquid chromatography/electrospray ionization multistage mass spectrometry - new biomarkers for biogeochemistry and microbial ecology. Rapid Commun Mass Spectrom 18: $617-628$

Taylor JD, Cunliffe M (2016) Multi-year assessment of 
coastal planktonic fungi reveals environmental drivers of diversity and abundance. ISME J 10:2118-2128

Taylor J, Parkes RJ (1983) The cellular fatty acids of the sulphate-reducing bacteria, Desulfobacter sp., Desulfobulbus sp. and Desulfovibvio desulfuvican. J Gen Microbiol 129:3303-3309

Thompson JD, Higgins DG, Gibson TJ (1994) CLUSTAL W: improving the sensitivity of progressive multiple sequence alignment through sequence weighting, position-specific gap penalties and weight matrix choice. Nucleic Acids Res 22:4673-4680

Tisthammer KH, Cobian GM, Amend AS (2016) Global biogeography of marine fungi is shaped by the environment. Fungal Ecol 19:39-46

Tolosa I, Vescovali I, Leblond N, Marty J, De Mora S, Prieur L (2004) Distribution of pigments and fatty acid biomarkers in particulate matter from the frontal structure of the Alboran Sea (SW Mediterranean Sea). Mar Chem 88: 103-125

Ulloa O, Delong EF, Letelier RM, Stewart FJ (2012) Microbial oceanography of anoxic oxygen minimum zones. Proc Natl Acad Sci USA 109:15996-16003

V Van Mooy BAS, Fredricks HF, Pedler BE, Dyhrman ST and others (2009) Phytoplankton in the ocean use non-phosphorus lipids in response to phosphorus scarcity. Nature 458:69-72

Ventura M (2006) Linking biochemical and elemental composition in freshwater and marine crustacean zooplankton. Mar Ecol Prog Ser 327:233-246

Vera J, Gutiérrez MH, Palfner G, Pantoja S (2017) Diversity of culturable filamentous Ascomycetes in the eastern South Pacific Ocean off Chile. World J Microbiol Biotechnol 33:157

Verma B, Robarts RD, Headley JV (2003) Seasonal changes in fungal production and biomass on standing dead Scirpus lacustris litter in a northern prairie wetland. Appl Environ Microbiol 69:1043-1050

Vestal JR, White D (1989) Lipid analysis in microbial ecology: quantitative approaches to the study of microbial communities. Bioscience 39:535-541

Vrede K, Heldal M, Norland S, Bratbak G (2002) Elemental composition $(\mathrm{C}, \mathrm{N}, \mathrm{P})$ and cell volume of exponentially growing and nutrient-limited bacterioplankton. Appl Environ Microbiol 68:2965-2971

Wallis IR, Claridge AW, Trappe JM (2012) Nitrogen content, amino acid composition and digestibility of fungi from a

Editorial responsibility: Jutta Niggemann,

Oldenburg, Germany nutritional perspective in animal mycophagy. Fungal Biol 116:590-602

*Walve J, Larson U (1999) Carbon, nitrogen and phosphorus stoichiometry of crustacean zooplankton in the Baltic Sea: implications for nutrient recycling. J Plankton Res 21:2309-2321

*Wang JT, Han T, Li XY, Hu SX, Jiang YD, Wang CL (2016) Effects of dietary phosphatidylcholine (PC) levels on the growth, molt performance and fatty acid composition of juvenile swimming crab, Portunus trituberculatus. Anim Feed Sci Technol 216:225-233

*Wang T, Tong S, Liu N, Li F, Wells ML, Gao K (2017) The fatty acid content of plankton is changing in subtropical coastal waters as a result of OA: results from a mesocosm study. Mar Environ Res 132:51-62

*Wang X, Singh P, Gao Z, Zhang X, Johnson ZI, Wang $G$ (2014) Distribution and diversity of planktonic fungi in the west Pacific warm pool. PLOS ONE 9: e101523

*Weete JD, Abril M, Blackwell M (2010) Phylogenetic distribution of fungal sterols. PLOS ONE 5:e10899

White TJ, Bruns S, Lee S, Taylor J (1990) Amplification and direct sequencing of fungal ribosomal RNA genes for phylogenetics. In: Innis MA (ed) PCR protocols: a guide to methods and applications. Academic Press, San Diego, CA, p 315-322

Whyte J (1987) Biochemical composition and energy content of six species of phytoplankton used in mariculture of bivalves. Aquaculture 60:231-241

*Wilcox TP, Zwickl DJ, Heath TA, Hillis DM (2002) Phylogenetic relationships of the dwarf boas and a comparison of Bayesian and bootstrap measures of phylogenetic support. Mol Phylogenet Evol 25:361-371

Wirth F, Goldani LZ (2012) Epidemiology of Rhodotorula: an emerging pathogen. Interdiscip Perspect Infect Dis 2012: 465717

Wörmer L, Lipp JS, Schröder JM, Hinrichs KU (2013) Application of two new LC-ESI-MS methods for improved detection of intact polar lipids (IPLs) in environmental samples. Org Geochem 59:10-21

* Zhang J, Elser JJ (2017) Carbon:nitrogen:phosphorus stoichiometry in fungi: a meta-analysis. Front Microbiol 8: 1281

Zhukova NV, Aizdaicher NA (1995) Fatty acid composition of 15 species of marine microalgae. Phytochemistry 39: 351-356

Submitted: March 18, 2019; Accepted: February 4, 2020

Proofs received from author(s): March 9, 2020 